\title{
СТАТУС БІЖЕНЦІВ В УКРАЇНІ ТА СВІТІ: ЗАГАЛЬНИЙ ОГЛЯД
}

Мішеніна А. С., Деркаченко Ю. В.

Нині проблема неповноти національного законодавства щодо визначення статусу біженця $\epsilon$ доволі актуальною. У законодавстві України з цього питання відсутня конкретизація. Звідси й протиріччя, непорозуміння та недостатня інформованість щодо набуття статусу біженця в Україні. Крім того, на практиці в Україні не застосовується або порушається виконавчими органами законодавство не тільки щодо процедури визначення статусу біженця, але й щодо прав біженців. Завдання статmі: на основі порівняльного аналізу міжнародного та національного законодавства знайти проблемні та недопрацьовані статті в законодавстві України, звернути увагу на те, які міжнародні договори містять детальне роз'яснення проблеми, розібратися, як держава контролює виконання законодавчих норм та актів щодо визначення статусу біженця. Завдяки використанню логічного та порівняльного методу здійснено аналіз національного законодавства щодо визначення статусу біженця на предмет достатньої інформативності та повноти статей. За допомогою аналітичного та системно-структурного методу виявлено особливості застосування законодавства. Вказано, які прогалини має національне законодавство та які саме теми потребують доопрацювання, зокрема: Закон України «Про біженців та осіб, яку потребують додаткового або тимчасового захисту» має містити більш детальну інформацію щодо порядку перереєстрації, який встановлюються Центральним органом виконавчої влади, що реалізує державну політику у сфері біженців та осіб, які потребують додаткового або тимчасового захисту, та не оприлюднений для загального доступу (процедуру перереєстраціі особі-біженцю необхідно проходити кожного року), інформацію щодо житла, яке надається в пункті тимчасового розміщення біженців (що необхідно, щоб скористуватись цією послугою; строк користування цим житлом та змога його подовжити; умови проживання), або доповнити ст. 13 Закону України «Про біженців та осіб, яку потребують додаткового або тимчасового захисту» посиланням на Постанову КМУ «Про порядок надання та користування житловими приміщеннями з фондів житла для тимчасового проживання» із вказівкою на певний пункт постанови. Досліджена правозастосовна практика в Україні щодо визначення статусу біженця. Визначено, що Україна, ратифікувавши необхідні конвенції та договори щодо прав біженців та процедури їх визначення, не імплементувала їх зміст у власне законодавство, що пояснює його недостатню інформативність. Також невиконання виконавчими органами законів щодо аналогічної теми вказує на недостатній рівень контролю за виконанням законодавства українською владою. Певна свавільність та «власне трактування законодавства» присутні у діях державних діячів Державної міграційної служби, де майже щодня порушуються права як біженця, так і людини загалом. Прикладами таких нерозважливих дій є доволі дивна заборона ДМС, яка не дає змоги міжнародним організаціям спілкуватися з особами, які знаходяться під опікою, багато заяв від біженців щодо корупції та утримування в нелюдських умовах.

Ключові слова: права біженців, обов'язки біженців, ратифікація міжнародних договорів, імплементація міжнародних договорів, начіональне законодавство, міжнародне законодавство.

Mishenina A. S., Derkachenko Yu. V. Refugee status in Ukraine and the world: overview

Today, the problem of national legislation incompleteness regarding determining refugee status is quite relevant. There is no specification on this issue in the legislation of Ukraine. Hence, there are some contradictions, misunderstandings and lack of awareness about the acquisition of refugee status in Ukraine. Moreover, in practice, the executive bodies of Ukraine do not apply or violate legislation not only on the procedure for determining refugee status, but also on refugee rights. Tasks Based on a comparative analysis of International and National legislation, to find problematic and incomplete articles in the legislation of Ukraine. To pay attention to the issue which international agreements contain a detailed explanation of this problem. Understand how the state monitors the implementation of legislation and acts on the refugee status determination. Using a logical and comparative method, the analysis of national legislation on determining refugee status was carried out to ensure that the articles are sufficiently informative and complete. Analytical and system-structural methods were used to identify the features of legislation application. International and national legislation of Ukraine was analyzed. It is indicated which gaps national legislation has and which topics need to be improved. Namely: The Law of Ukraine "On Refugees and Persons in Need of Additional or Temporary Protection" should contain more detailed informa-

(c) Мішеніна А. С., Деркаченко Ю. В., 2020 
tion on: re-registration procedure established by the Central Executive Body, which implements the state policy in the field of refugees and persons in need of additional or temporary protection, and is not made public (refugee re-registration procedure is required every year); information on housing provided at the temporary accommodation of refugees (what is necessary to use this service; the term of use of this housing and the possibility of its extension; living conditions), or supplement Article 13 of the Law of Ukraine "On Refugees and Persons in Need of Additional or Temporary Protection" with a reference to the Resolution of the Cabinet of Ministers "On the Procedure for Providing and Using Housing from Temporary Housing Funds" with reference to a specific paragraph of this resolution. The article examines the law enforcement practice in Ukraine regarding determining refugee status. It was determined that Ukraine, having ratified the necessary conventions and treaties relating to refugee rights and the procedure for determining them, did not implement their content in its own legislation, which explains the lack of information. Also, the failure of executive bodies to comply with laws on a similar topic indicates an insufficient level of control over the implementation of legislation by the Ukrainian authorities. Certain self-will and "own interpretation of legislation" are present in the actions of state officials of the State Migration Service, where the rights of both refugees and individuals are violated almost daily. Examples of such reckless actions are a rather strange ban of the DMS, which does not allow International organizations to communicate with people who are under guardianship, a lot of statements from refugees about corruption and detention in inhumane conditions.

Key words: refugee rights, refugee obligations, ratification of international treaties, implementation of international treaties, national legislation, international legislation.

Постановка проблеми та іï актуальність. У сучасному світі та в Україні зокрема проблема визначення статусу біженців $\epsilon$ надзвичайно актуальною. На збільшення кількості біженців впливають збройні конфлікти в Центральній Африці, Сирії, країнах Східної Азії тощо. Після анексії Криму та часткової окупації Донецької та Луганської областей біженці були змушені шукати притулку в інших містах України та в інших країнах. Але не тільки війна спонукає людей шукати притулку в інших країнах - причинами біженства $\epsilon$ також низький рівень життя в країнах, таких як Нігерія та Конго.

Цілком очевидно, що особливого значення тут набуває процедура визначення статусу біженця, пов'язана 3 визначенням права на притулок та його набуттям. Зокрема, А. Тарасова започатку- вала дослідження юридичної процедури як засобу забезпечення реалізації прав та свобод людини i громадянина, де під процедурою розуміється системне загальне соціальне явище, орієнтоване на досягнення конкретного соціального статусу та результату [1, с. 146-147]. Н. Шестакова виділяє три стадії процедури надання статусу біженця в Україні (порушення справи після подання особою заяви, порядок попереднього розгляду заяв, прийняття рішення) [2, с. 147]. О. Середа описує правову процедуру як цільову зв'язаність певних нормативно-врегульованих дій, які можуть проявлятись у диспозитивній та імперативній формах. На думку автора, ці дії мають певні строки та, як наслідок, юридичну фіксацію [3].

Г. Гудвін-Гілл (Goodwin-Gill) визначає внутрішньо переміщених осіб як осіб, що змушені масово та раптово тікати зі своїх будинків через збройні конфлікти, внутрішню ворожнечу, систематичні порушення прав людини або через стихійні лиха [4]. Р. Альба та В. Hi (Alba and Nee) розглядали теорію асиміляції та пов'язували іiі з інтеграцією мігрантів, акцентуючи на тому, що ця теорія не втратила своєї корисності донині [5]. Своєю чергою М. Беллоні (Belloni) описує взаємозв'язок між потоками біженців, політикою та іншими макро-соціально-економічними та культурними факторами, вказує, що Дублінська постанова не запобігає вторинним переміщенням на території Європи, проводить етнографічне дослідження, як еритрейські біженці в Італії вирішують переїжджати в інші європейські країни [6].

E.I. Теволд (Tewolde) висвітлює тактику перетину кордону мігрантами з південної частини Африки в контексті ксенофобії у Південній Африці після апартеїду [7]; Р. Ярбро (Yarbrough) вивчає проблему расизму та дискримінації мігрантів із Латинської Америки у США, описує теорію расовості та інтерв'ю з іммігрантами з Центральної Америки в Атланті, котрі приймають расову латиноамериканську ідентичність через складний процес сприйняття думки оточуючих та самоідентифікацію [8].

Міжнародне право розглядалося усіма доволі прискіпливо, але українське законодавство не досліджувалося на предмет неповної інформативності певних статей або відсутність необхідної інформації.

Метою статті $\epsilon$ визначення особливостей правового регулювання визначення статусу біженців.

Новизна статті полягає у формуванні та обґрунтуванні таких пропозицій: доповнити 
текст ст. 13 п. 1 Закону України «Про біженців та осіб, які потребують додаткового або тимчасового захисту» інформацією щодо умов та процесу надання житла з фондів для тимчасового проживання; опублікувати порядок перереєстрації біженців за місцем проживання; на основі рекомендацій, прописаних у Конвенції про статус біженців, розробити кращу систему контролю над правами та обов'язками біженців.

Завданням статті $€$ висвітлення міжнародного та національного законодавства щодо визначення статусу біженця нормативно-правових актів, щодо визначення статусу біженця, прав та обов'язків біженців в Україні.

Виклад основного матеріалу. За останні півтора століття проблема міграції отримала належне розв'язання [9, с. 59]. Найважливіші поняття у ній «мігрант» $\mathrm{i}$ «біженець». Мігранти - це особи, котрі здійснюють міграцію, тобто перетинають державні або адміністративно-територіальні кордони з метою зміни місця проживання назавжди, на певний час чи з метою отримати роботу. Мігранти $\epsilon$ найчисельнішими суб'єктами переміщення. Біженцем $€$ особа, яка не $\epsilon$ громадянином країни, що надала притулок, але була змушена покинути місце постійного проживання на території іншої держави внаслідок вчиненого щодо неї або членів iї сім'ї насильства, переслідування або небезпеки переслідування внаслідок расових, релігійних, національних, політичних чи мовних переконань або через збройні чи міжнаціональні конфлікти. Поняття «мігрант» $\mathrm{i}$ «біженець» за своїм смисловим навантаженням $є$ різними - спільною рисою $\epsilon$ лише можливість їх переміщення через кордон держави, що характеризує «міжнародну міграцію» $[10$, с. 79$]$.

Характерним $€$ постійне збільшення кількості мігрантів і біженців - на рисунку 1 подана динаміка міграції та біженців у світі за 2000-2019 рр.

Міжнародне право з прав біженців має завдання забезпечити гуманне поводження з людьми або групою людей, що $є$ найуразливішими. Своєю чергою міжнародне право з прав людини має за головне зберегти честь та гідність та благополуччя людини. Тому ці два міжнародних права тісно взаємопов'язані [11, с. 131].

Законодавство про біженців і права людини тісно взаємозв’язані. Таке явище, як «біженці», породження гонінь, пригнічення особи людини, обмежень його основних прав і свобод. Фактично законодавство про біженців $\epsilon$ складовою частиною законодавства про права людини i адресовано воно такій специфічній групі, як біженці [12, с. 95]. Конвенція про статус біженців від 1951 р. $€$ основним правовим документом, який регулює відносини у цій сфері. Залежно від того, з якої підстави особа може бути визнана біженцем, застосовується багато правових норм: Загальна декларація прав людини від 10.12.1948 р. (якщо особа є об'єктом переслідування); додатковий протокол до Женевської Конвенції від 12.08.1949 р. (якщо особа $є$ об'єктом переслідування у зв'язку зі збройними конфліктами); Конвенція з прав дитини від 20.11.1989 р. (якщо особа $\epsilon$ неповнолітньою); стандарти, визначені в Укладеннях Виконкому Управління Вер-

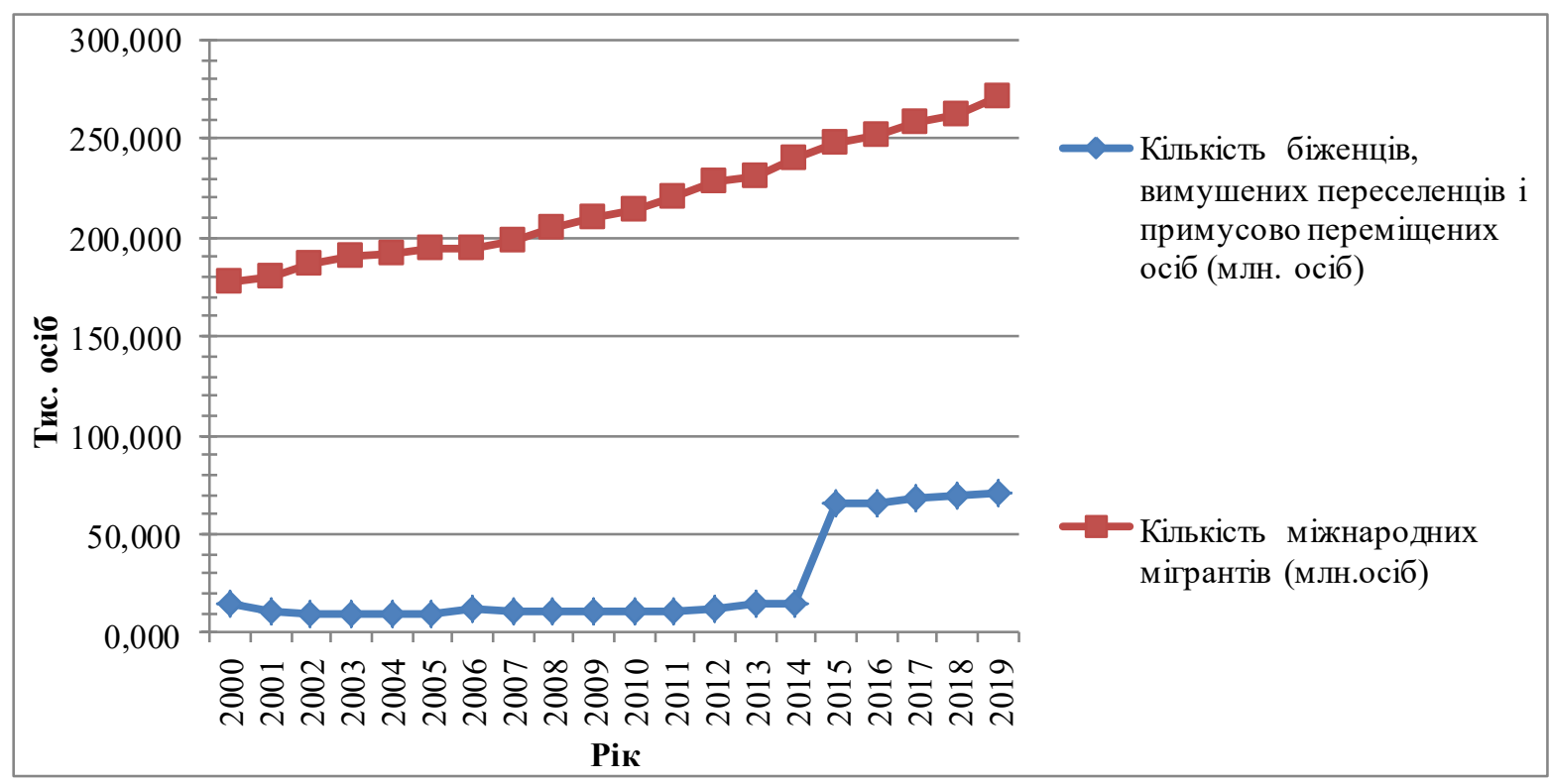

Рис. 1. Динаміка міграції та біженців у світі за 2000-2019 рр. 
ховного комісара Організації Об'єднаних Націй у справах біженців, що $є$ в міжнародних договорах про захист прав людини (норми, що стосуються поводження з біженцями в країні-притулку); Міжнародний пакт про громадянські і політичні права (надає права всім затриманим біженцям та право на незалежний розгляд законності затримання); Конвенція проти катувань та інших жорстоких, нелюдяних або видів звернення і покарання, що принижують гідність від 1987 р. (як додаткове джерело захисту).

Критерії визначення біженців поділяються на три види. Перший включає в себе критерії включення (характеристики, які притаманні особібіженцю). Другий вид містить критерії виключення (характеристики особи, яка не може буди визнана біженцем). Третій вид описує критерії припинення (підстави, через які особа-біженець може бути позбавлена цього статусу) [3, с. 27].

Існують три принципи міжнародного захисту прав біженців: принцип невисилки, принцип конфіденційності, принцип недискримінації. Цим принципам властиві ознаки міжнародного права. На них базуються взаємодія суб'єктів та процес створення та реалізації норм права в цій галузі. Вони мають універсальну сферу дії, деталізуються міжнародно-правовими актами та визначають методи співпраці суб'єктів міжнародного права. Ці принципи є доволі специфічними. Першочергово вони закріплені в міжнародному законодавстві з прав людини, але в галузі прав біженців вони мають особливе, притаманне лише цій галузі значення.

Цінності, яка захищає ця норма, $є$ такими, що становлять «основу цивілізації». Права людини дають певні гарантії, що захищають окремих осіб, уразливі групи від певних дій чи бездіяльності.

Міжнародний захист прав та інтересів біженців -єдиний та найбільш ефективний інструмент на сьогоднішній день. Саме в міжнародному праві виділені три основні принципи захисту прав біженців. Нижчеописані значущі принципи мають особливе положення: найважливіші, корінні та $\epsilon$ нормативною основою усіх систем, що стосуються інституту права біженців.

Принцип недискримінації (jus cogens). Цей принцип закріплений у міжнародно-правових договорах, виконання яких гарантується. Принцип недискримінації забороняє необгрунтоване відмінне ставлення через певні ознаки до осіб, які перебувають в однаковій ситуації, або однаковий підхід до осіб, які перебувають у відмінній ситуації. Серед випадків, до яких можна застосувати цей принцип, - обмеження у визнанні, користуванні правами та свободами або реалізації, якщо такі обмеження $\epsilon$ наслідком дискримінації.

Принцип невисилки (non-refoulement) в міжнародному праві біженців. Цей принцип $\epsilon$ спеціальним та засадничим. Вперше був закріплений у ст. 3 Конвенції про міжнародний статус біженців від 1933 р. Генеральна Асамблея ООН зобов'язала Управління Верховного комісара Організації Об'єднаних націй у справах біженців надавати допомогу біженцям, які мають право на захист за попередніми договорами. Принцип невисилки - це основа права людини шукати та користуватися притулком, що підтверджується ст. 14 Загальної декларації прав людини. Основна суть принципу non-refoulement - заборона примусової висилки чи повернення біженців різними способами до країни, де існує загроза їхньому життю чи свободі. У Законі України «Про біженців та осіб, які потребують додаткового або тимчасового захисту» у ст. 3 дублюється заборона, вказана вище [13].

Принцип конфіденційності в міжнародному праві біженців має особливе значення у процедурі визначення статусу біженця, якщо точніше, під час співбесіди. У міжнародному праві кожному гарантується конфіденційність та захист від незаконних втручань в особисте і сімейне життя. Підтвердження тому можна знайти в таких юридичних нормах: Загальна декларація прав людини (ст. 12); Конвенція ООН про працівників-мігрантів (ст. 16); Міжнародний пакт про громадянські й політичні права (ст. 17); Конвенція ООН про права дитини (ст. 16). Тобто конфіденційність - фундаментальне право людини, яке пов'язане з людською гідністю та іншими важливими цінностями.

Метою визначення статусу біженця $\epsilon$ перевірка відповідності особи, яка потребує притулку, згідно з критеріями міжнародної адвокації біженців.

Виконавчий комітет Управління Верховного комісара у справах біженців Організації Об'єднаних Націй розробив вимоги до процедури визначення статусу біженця для усіх держав, що приєдналися до Конвенції і Протоколу про біженців [14, с. 112]: забезпечити інформованість заявника про процедуру, право на оскарження рішення, доступ заявника до території і процедури, перебування в країні на термін розгляду клопотання й оскарження рішення в судовому порядку, наявність органу, відповідального за проведення процедури, зв'язок із представниками УВКБ ООН. 
В Україні система контролю над виконанням та забезпеченням усіх необхідних вимог $є$ нерозвиненою. Незабезпеченість належного контролю призводить до таких наслідків, як невиконання або неналежне виконання законодавчо прописаних норм та правил проведення процедури з визначення статусу біженців. Прикладом цього може бути заборона Державної міграційної служби щодо спілкування затриманих осіб або осіб, що очікують на рішення щодо їхнього статусу, з представниками міжнародних організацій. Ця дія $є$ проявом неповаги до людей та міжнародних організацій, також їі можна розцінювати як дії, що порушують права людини.

Закон України «Про біженців та осіб, які потребують додаткового або тимчасового захисту» [13] в ст. 13 містить інформацію щодо прав та обов'язків особи, чиї документи про надання статусу біженця прийняті до оформлення. Але $\epsilon$ деякі питання щодо змісту статті. Наприклад, особа має право проживати в готелі, орендувати житло, жити в родичів або користуватися житлом, яке надається в пункті тимчасового розміщення біженців. Щодо останнього виникає низка запитань. На який максимальний строк житло видається? Яких умов проживання слід очікувати? Що потрібно зробити, щоб скористуватись цією державною послугою? Відповіді на ці питання можна знайти лише у Постанові КМУ «Про порядок надання та користування житловими приміщеннями з фондів житла для тимчасового проживання» [15]. У п. 3 цієї постанови вказано, що житлові приміщення з фондів житла видаються за рішеннями виконавчих органів сільських, селищних та міських рад. Але в цій постанові вказано, що надається воно біженцям, які набули цього статусу відповідно до Закону України «Про біженців». Тобто якщо особа, чиї документи тільки оформлюються, звернеться до відповідних органів, скоріш за все вона отримає відмову у наданні житла. У цьому пункті також написано, що на одну особу

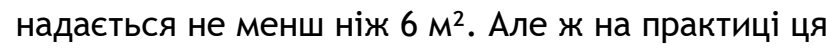
інформація сприймається буквально. Тому можна розраховувати на те, що разом із вами проживатиме ще певна кількість осіб [15, п. 3]. Інформація щодо терміну проживання міститься у п. 5 цієї ж постанови. Такі житлові приміщення надаються громадянам на строк до одного року з можливістю продовження цього терміну. Але продовжити термін можна, якщо особа неспроможна набути альтернативне місце проживання [15, п. 5].

Особа, чиї документи подані на оформлення статусу біженця, згідно зі ст. 13 Закону України
«Про біженців та осіб, які потребують додаткового або тимчасового захисту» [13], має такі зобов'язання: звернутися до центрального органу виконавчої влади (далі - ЦОВВ), який реалізує державну політику у сфері біженців та осіб, які потребують додаткового захисту, та подати необхідні відомості для визнання статусу біженця цієї особи; пройти медичне обстеження на вимогу ЦОВВ; з'являтися до ЦОВВ у визначений строк; повідомляти ЦОВВ про будь-які поїздки за межі адміністративно-територіальної одиниці України, на якій проживає особа.

Незважаючи на те, що в Україні $\epsilon$ законодавство, яке регулює процедурні елементи визначення статусу біженця та вказує на те, якими послугами можуть або мають користуватися біженці, воно все ж має недоліки: відсутність якісних послуг із перекладу: документів, розмов з уповноваженими посадовими особами; від біженців вимагають підтвердження реєстрації місця проживання; доволі висока плинність кадрів серед державних службовців; якщо шукачам притулку відмовлено - не надається жодної інформації про причину відмови; дуже короткий термін на подання скарги; багато скарг надходить від біженців щодо випадків корупції.

Також ми хочемо акцентувати на тому, що в Україні осіб, які перебувають у країні без законних підстав, обвинувачують в адміністративному правопорушенні. На практиці таке трапляється, коли особа намагається в'їхати до країни без необхідної візи або паспорту. Як наслідок, їх примусово повертають або видворяють з України. Їх направляють до пункту тимчасового перебування іноземців. Такі пункти є у Миколаївській, Волинській та Чернігівській областях. Максимальний термін утримання під вартою в таких установах становить 18-24 місяці. А судовий перегляд проводиться лише кожні 6 місяців, що $є$ доволі довгим терміном для розгляду таких справ.

32018 р. ДМС України обмежила доступ до осіб, які знаходяться під опікою, міжнародним організаціям у справах біженців. Але без допомоги таких організацій у затриманих осіб практично немає шансів на своєчасний та справедливий судовий перегляд справи. Тим паче, що міжнародне законодавство з прав біженців $є$ більш змістовим та створене, щоб допомагати, а не калічити. Хоч Україна приєдналась до Конвенції з прав біженців, але, з огляду на дії уповноважених державою осіб, неохоче її запроваджує.

Права біженця та особи, яка потребує додаткового захисту, описані у ст. 15 ЗУ «Про біженців та осіб, які потребують додаткового або тимчасо- 
вого захисту». У цій статті акцентується на тому, що особа зі статусом біженця має рівні з громадянами України права, такі як право на вільне пересування (як на території України, так і за їі межами), вибір місця проживання, працю, підприємницьку діяльність, медичну допомогу і т.д. [13].

Крім прав, у біженця єй обов' язки перед державою. Ст. 16 висвітлює їх доволі докладно. Наприклад, особа, що визнана біженцем, має звітувати до ЦОВВ, що реалізує державну політику у сфері біженців та осіб, які потребують додаткового або тимчасового захисту, з приводу низки обставин (зміна прізвища, сімейний стан, зміна місця проживання, набуття громадянства України або іншої держави, надання притулку в іншій країні). Але це не повний перелік обов'язків особи-біженця перед Україною. Якщо особа з цим статусом хоче змінити місце проживання (наприклад, переїхати до іншого міста в Україні), треба знятися з обліку у ЦОВВ міста, де нині перебуває, та стати на облік того міста, куди прагне переїжджати.

Також біженцю потрібно проходити щорічну перереєстрацію у строк, який встановлює ЦОВВ, що реалізує державну політику у сфері біженців та осіб, які потребують додаткового або тимчасового захисту, за місцем проживання. Ця щорічна дія дасть змогу особі продовжити строк дії посвідчення біженця. Порядок перереєстрації встановлюється тим самим цОВВ. Але інформації щодо цього порядку немає у вільному доступі. Це i $\epsilon$ одним із показників того, що українське законодавство не є змістовним. Ми вважаємо за необхідне оприлюднення цього порядку перереєстрації, що зробить цю процедуру більш «прозорою» та інформаційно доступною для певної категорії осіб (ст. 15) [13].

У Протоколі щодо статусу біженця міститься деталізація самого поняття «біженець» за часовою ознакою [16; 17]. Запровадження цього протоколу було необхідним, бо у Конвенції про статус біженців 1951 р. існували деякі обмеження щодо поняття «біженець». Ці обмеження заважали забезпеченню прав та свобод, вирішенню проблем біженців [18; 19].

Декларація ООН про територіальний притулок від 1967 р. описує право будь-якої особи на притулок та його використання, уточнюючи, що за певних підстав деякі особи все ж не мають права на надання притулку (особа, щодо якої є обґрунтовані підозри, особа, що вчинила злочин проти миру, військовий злочин або злочин проти людства). Ця Декларація містить та закріплює основний гумані- тарний принцип - «заборона примусового повернення» [19].

У Конвенції про статус біженців від 1951 р., яку Україна ратифікувала 10.01.2002 р., детальніше розтлумачені права та обов'язки особи-біженця, а також $\epsilon$ інформація, як держава має сприяти їх втіленню та контролю. Після ратифікації цього документа необхідна імплементація його вмісту в національне законодавство, що українською владою не було зроблено у повному обсязі.

Висновки. Встановлена низька інформативність українського законодавства щодо визначення статусу біженців: у п. 1 ст. 13 Закону України «Про біженців та осіб, які потребують додаткового або тимчасового захисту» слід внести детальний опис процесу та умов надання цього житла або зробити посилання на п. 3 Постанови Кабінету Міністрів України «Про порядок надання та користування житловими приміщеннями 3 фондів житла для тимчасового проживання», де міститься необхідна інформація.

У разі відсутності у вільному доступі інформації про порядок проведення процедури перереєстрації вказано, що його встановлює ЦОВВ, що реалізує державну політику у сфері біженців та осіб, які потребують додаткового або тимчасового захисту, за місцем проживання. Це призводить до «непрозорості» цього процесу - запропоновано затвердити єдиний порядок перереєстрації біженців для усіх центральних органів виконавчої влади, що реалізують державну політику у сфері біженців та осіб, які потребують додаткового або тимчасового захисту.

Потрібно вдосконалити систему державного сприяння та контролю щодо прав та обов'язків біженців, спираючись при цьому на рекомендації Конвенції про статус біженців від 1951 р.

\section{Література}

1. Тарасова А.Г. Юридические процедуры и реализация прав человека: теоретико-правовой аспект : автореф. дис. ... канд. юрид. наук : 12.00.01. Волгоград, 2015. 22 с

2. Шестакова Н.О. Основні аспекти визначення поняття «біженець» в міжнародному праві. Вісник Дніпропетровського університету імені Альфреда Нобеля. Серія «Юридичні науки». 2015. № 2 (7). С. 26-30.

3. Середа 0.0. Правова процедура - поняття та ознаки. Влада і суспільство: проблеми взаємодії : матеріали Всеукраїнської наук.-практ. конф., м. Запоріжжя, 18-19 листопада 2005 р. Запоріжжя : 
Вид-во Запорізького юрид. інституту МВС України, 2005. С. 56-58.

4. Goodwin-Gill G.S., Jane McAdam. The Refugee in International Law. Oxford : Oxford University Press, 2007. 786 p.

5. Alba, R., \& Nee, V. (1997). Rethinking assimilation theory for a new era of immigration. The International Migration Review, 31(4), 826-874. doi: htpp://doi.org/ $10.2307 / 2547416$.

6. Belloni, M. (2016). Refugees as gamblers: Eritreans seeking to migrate through Italy. Journal of Immigrant \& Refugee Studies, 14(1), 104-119. doi: htpp: / /doi.org/10.1080/15562948.2015.1060375.

7. Tewolde, A.I. (2017). How Eritreans in South Africa talk about their refugee experiences: A discursive analysis. South African Review of Sociology, 48(3), 3-20. doi: htpp://doi.org/10.1080/21528586.2017.13 88607.

8. Yarbrough, R. A. (2010). Becoming 'Hispanic' in the 'New South': Central American immigrants' racialization experiences in Atlanta, GA, US. Geo Journal, 75(3), 249-260. doi: htpp://doi.org/10.1007/ s10708-009-9304-7.

9. Свящук А.Л. Проблеми прав біженців та виклики сучасності: навчальний посібник. Харків : Видавництво «ФОП Голембовська О.О.», 2018. 321 с.

10. Кхасраві 0.3. Співвідношення понять «мігрант», «біженець», «переселенець», «внутрішньо переміщена особа». Науковий вісник Міжнародного гуманітарного університету. 2016. № 20. С. 77-80.

11. Котляр О. Місце в інституту біженців в міжнародному праві. Visegrad Journal on Human Right. 2016. № 6. С. 131-136.

12. Кухтик С.В., Деркаченко Ю.В. Імміграція та адвокація прав біженців і внутрішньо переміщених осіб : навчальний посібник. Київ : Видавництво «ФОП Голембовська О.0.», 2018. 394 с.

13. Про біженців та осіб, які потребують додаткового або тимчасового захисту : Закон України від 03.03.2016 p. № 16. URL: https://zakon.rada.gov.ua/ laws/show/3671-17\#Text
14. Чуєнко B.І. Принципи міжнародно-правового статусу біженців. Право та інновації. 2018. № 2. C. 111-118.

15. Про затвердження Порядку формування фондів житла для тимчасового проживання та Порядку надання і користування житловими приміщеннями з фондів житла для тимчасового проживання : Постанова Кабінету Міністрів України від 31.03.2004 p. № 422. URL: https: / / zakon.rada.gov.ua/ laws/show/422-2004-п\#Text.

16. Протокол щодо статусу біженця від 1967 року / ратифікація від 10.01.2002 р. № 2942-III. URL: https:// zakon.rada.gov.ua/laws/show/995_363\#Text.

17. Handbook on procedures and criteria for determining refugee status and guidelines on international protection under the 1951 convention and the 1967 protocol relating to the status of refugees reissued geneva. UNHCR, 2019. 253 p.

18. Конвенція про статус біженців від 1951 р. / ратифікація від 10.01.2002 р. № 2942-III. URL: https://zakon.rada.gov.ua/laws/show/995_011\#Text.

29. Декларація ООН про територіальний притулок від 14.12.1967 p. URL: https://zakon.rada.gov.ua/ laws/show/995_316\#Text.

20. International Organization for Migration. URL: https://www.iom.int.

21. UNDP in Ukraine. URL: https://www.ua.undp. org/content/ukraine/uk/home.html.

22. Migration data portal. URL: https:// migrationdataportal.org/?i=stock_abs_\&t=2019.

мішеніна А. С., магістр права

Міжнародного науково-технічного університету імені академіка Юрія Бугая

Деркаченко Ю. В., кандидат юридичних наук, доцент кафедри права

Міжнародного науково-технічного університету імені академіка Юрія Бугая 